\title{
Chapter 1 \\ Research Papers: Titles and Abstracts
}

\section{Whole paper: Concentrate above all on readability; grammar is generally less important.}

MISTAKE I have surveyed thousands of $\mathrm{PhD}$ students about what they consider to be the fundamentals of writing research papers in English. While some recognize that readability should be prioritized (i.e. minimizing long sentences and redundancy), most tend to focus on grammar and vocabulary. Few mention conciseness and even fewer mention ambiguity. In my opinion, it is a mistake to think that good grammar and appropriate vocabulary are the key to a good paper. There are other elements, including the ones listed below, that are much more likely to determine whether your paper will be accepted for publication, and which have a big impact on what a reviewer might refer to as 'poor English'. This whole book is designed to help you understand what areas you should really be concentrating on.

\section{SOLUTION}

- Always think about the referee and the reader. Your aim is to have your paper published. You will increase your chances of acceptance of your manuscript if referees and journal editors (i) find your paper easy to read; (ii) understand what gap you filled and how your findings differ from the literature. You need to meet their expectations with regard to how your content is organized. This is achieved by writing clearly and concisely, and by carefully structuring not only each section, but also each paragraph and each sentence.

- In your own native language, you may be more accustomed to write from your own perspective, rather than the reader's perspective. To write well in English, it may help you to imagine that you are the reader rather than the author. This entails constantly thinking how easily a reader will be able to assimilate what you the author are telling them. 
- Write concisely with no redundancy and no ambiguity, and you will make fewer mistakes in your English. The more you write, the more mistakes in English you will make. If you avoid redundant words and phrases you will significantly increase the readability of your paper.

- Read other papers, learn the standard phrases, use these papers as a model. You will improve your command of English considerably by reading lots of other papers in your field. You can underline or note down the typical phrases that they use to express the various language functions (e.g. outlining aims, reviewing the literature, highlighting their findings) that you too will need in your paper. You can also note down how they structure their paper and then use their paper as a template (i.e. a model) for your own.

\section{IMPACT}

If your paper is relatively easy to read and each sentence adds value for the reader, then you are much more likely to be cited in other people's work. If you are cited, then your work as an academic will become more rewarding - people will contact you and want to work with you.

More details about readability and being concise can be found in Sections 31-56. 


\section{Titles: Ensure your title as specific as possible. Delete unnecessary words.}

\begin{tabular}{|c|c|}
\hline NO! & YES! \\
\hline $\begin{array}{l}\text { 1) The design of an XYZ system for } \\
\text { implementing ABC. }\end{array}$ & An XYZ system for implementing ABC. \\
\hline $\begin{array}{l}\text { An investigation into the modeling of } \\
\text { the XYZ process. }\end{array}$ & An $\mathrm{ABC}$ for modeling the $\mathrm{XYZ}$ process. \\
\hline $\begin{array}{l}\text { The development of an } \mathrm{XYZ} \text { tool for } \\
\text { predicting } \mathrm{ABC} \text {. }\end{array}$ & An XYZ tool for predicting ABC. \\
\hline A study of a novel $\mathrm{ABC}$ system. & Integrating $\mathrm{XYZ}$ into an $\mathrm{ABC}$ system. \\
\hline Some insights into XYZ. & $\begin{array}{l}\mathrm{XYZ} \text { - is it really the best method for solving } \\
\mathrm{ABC} \text { ? }\end{array}$ \\
\hline $\begin{array}{l}\text { 2) Se nanoparticles treatment of tomato } \\
\text { as a tool to prolong the shelf life of the } \\
\text { fruits. }\end{array}$ & $\begin{array}{l}\text { Treating tomato with Selenium nanoparticles } \\
\text { prolongs the shelf life. }\end{array}$ \\
\hline $\begin{array}{l}\text { 3) Selenium enrichment affects the } \\
\text { quality and post-harvest storage of basil } \\
\text { leaves. }\end{array}$ & $\begin{array}{l}\text { Selenium enrichment enhances the quality of } \\
\text { basil leaves and increases post-harvest storage by } \\
\text { up to five days. }\end{array}$ \\
\hline
\end{tabular}

MISTAKE Titles are often written without too much thought. The result is vague titles that don't give much information to the reader, and consequently dramatically decrease the chances of your paper being read. A paper might be rejected simply because the title and the content of the paper do not match. The title is the first thing that reviewers read, so you don't want to mislead them. In fact the title tends to be the benchmark against which reviewers assess the content of the paper.

Example 1: The first 3-4 words of all these titles give no information. By deleting these no-info words, the key words (ABC and XYZ) are shifted to the beginning of the title.

Example 2: as a tool to could simply be replaced with to. In the YES example, the title has been reformulated into a statement / conclusion. This can be a really effective way to tell readers what your main finding is. But check other titles in your journal to see whether such statements are used by other authors (some editors don't like this style).

Example 3: The NO example seems specific, but it isn't. It doesn't say how it affects quality and storage. 
SOLUTION Before you write your title, make a list of all the key words associated with your paper and your key findings (i.e. what makes your research unique). Put these key words and findings in order of priority. Now try to put the most important key word(s) as close as possible to the beginning of the title. Next ensure that the resulting title contains a definite and concise indication of what is written in the paper itself and somehow includes your key finding. Consider avoiding acronyms and abbreviations $(S e=$ selenium, but Google Scholar and other indexes may not know this).

IMPACT The title should contain as many key words as possible to help both the reader and search engines identify the key concepts. By including, if you can, your key finding(s) in your title you will have created a mini abstract that helps the reader to understand the importance of your paper.

You may find the following books helpful when writing a research paper:

English for Writing Research Papers

https://www.springer.com/gp/book/9783319260921

English for Academic Research: Writing Exercises

https://www.springer.com/gp/book/9781461442974

English for Academic Research: Grammar Exercises

https://www.springer.com/gp/book/9781461442882

English for Academic Research: Vocabulary Exercises

https://www.springer.com/gp/book/9781461442677 


\section{Titles: Avoid 'clever' titles.}

\begin{tabular}{|l|l|}
\hline NO! & YES! \\
\hline $\begin{array}{l}\text { 1) A hidden world inside rice seeds: Indol } \\
\text { acetic acid production and amylase activity } \\
\text { from endophytes bacteria. }\end{array}$ & $\begin{array}{l}\text { Indol acetic acid production and amylase } \\
\text { activity from endophytes bacteria. } \\
\text { Indol acetic acid production and amylase } \\
\text { activity from endophytes bacteria: the hidden } \\
\text { world inside rice seeds. }\end{array}$ \\
\hline $\begin{array}{l}\text { 2) First insights into the enhancement of } \\
\text { insecticide activity by a physical mixture } \\
\text { with cyclodextrin: a wizard's cauldron or a } \\
\text { chance to explore? }\end{array}$ & $\begin{array}{l}\text { A physical mixture with } \beta \text {-cyclodextrin } \\
\text { enhances the insecticide efficacy of } \\
\text { Diflubenzuron. }\end{array}$ \\
& $\begin{array}{l}\text { Enhancing insecticide activity using a } \\
\text { physical mixture with cyclodextrin: a witch's } \\
\text { cauldron or an opportunity? }\end{array}$ \\
\hline
\end{tabular}

MISTAKE

Example 1: The NO example is correct, but the first words don't really give an idea of what the paper is about. Moreover, no search engine is going to be looking for 'hidden world' as a key word. If you really want to use such a device, then put it at the end of the title. This creates a two-part title (second YES example) using a colon in the middle. This is a very useful means to shift key information to the beginning, but still retain a more fun or colloquial tone.

Example 2: The NO example is not a great title: i) it begins with a generic expression (first insights) and the second part contains a vocabulary mistake (it should be witch's not wizard's) and what does a chance to explore mean? Making mistakes with vocabulary is typical when you try to write a non-technical title. The result is that you give readers an initial bad impression, which may discourage them from reading the rest of the paper. And how many non-natives are going to know what a witch's cauldron is?

SOLUTION AND IMPACT Show your title to as many of your colleagues as you can. Ask them if they can improve it by making it more specific and so that it will immediately make sense to the editor and reviewers. Note: If you are particularly pleased with your title because to you it sounds clever or witty, consider rewriting or at least check that other people agree with you! 


\section{Abstracts: Be concise - especially in the first sentence.}

\begin{tabular}{|c|c|}
\hline NO! & YES! \\
\hline $\begin{array}{l}\text { Worldwide there are millions of daily } \\
\text { smokers who consume trillions of } \\
\text { cigarettes. This determines that cigarette } \\
\text { butts are one of the most common types of } \\
\text { litter in the world, present in any } \\
\text { environment, from the sea to the mountains } \\
\text { and from the countryside to the city. These, } \\
\text { due to the materials and toxic substances } \\
\text { that they contain, are waste with a very high } \\
\text { damaging potential for the environment and } \\
\text { for living organisms. The solutions applied } \\
\text { to try to combat it are still few and scarcely } \\
\text { sustainable and, therefore, alternative } \\
\text { solutions to landfilling or incineration } \\
\text { practices are necessary. }\end{array}$ & $\begin{array}{l}\text { Trillions of cigarettes are smoked daily, } \\
\text { making cigarette butts one of the most } \\
\text { common types of litter in the world. Due to } \\
\text { the materials and toxic substances that they } \\
\text { contain, this waste has a very harmful risk for } \\
\text { the environment and for living organisms. A } \\
\text { few barely sustainable solutions have tried to } \\
\text { combat this waste and alternative solutions to } \\
\text { landfilling or incineration are needed. }\end{array}$ \\
\hline
\end{tabular}

MISTAKE The style of an abstract likely reflects the style of the whole paper. Readers may find the NO! style confusing and thus the essence of the meaning is lost. They may also think that if the abstract is full of redundant words, then the rest of the paper is likely to be full of redundancy too. Readers may thus decide not to read the paper.

SOLUTION Only provide the reader with what is strictly necessary. Reducing the number of words will also help you meet the word count set by the journal (i.e. the maximum number of words that you can use in an abstract).

IMPACT The YES! version is more concise, dramatic and memorable, but with no loss of information. It contains $30 \%$ fewer words - this will enable you to i) respect the journal's word count requirements of the abstract; ii) free up more space for providing extra details. You want your Abstract to seem professional. If the English is poor and there is much redundancy the reader may see this as a sign of unclear thinking (as well as unclear English) and may then even doubt the whole research method. 


\section{Abstracts: Don't begin the abstract with non key words.}

\begin{tabular}{|c|c|}
\hline NO! & YES! \\
\hline $\begin{array}{l}\text { During the last } 50 \text { years, research has focused } \\
\text { on the development of an effective control } \\
\text { algorithm for prosthesis application. }\end{array}$ & $\begin{array}{l}\text { An effective control algorithm for } \\
\text { prosthesis application has been the subject } \\
\text { of research for around } 50 \text { years. }\end{array}$ \\
\hline $\begin{array}{l}\text { This paper was aimed at assessing } \\
\text { retrospectively the rate of paroxysmal } \\
\text { sympathetic hyperactivity using the } \\
\text { Paroxysmal Sympathetic Hyperactivity- } \\
\text { Assessment Measure (PSH-AM) scale in } \\
\text { patients with severe consciousness disorders. }\end{array}$ & $\begin{array}{l}\text { The rate of paroxysmal sympathetic } \\
\text { hyperactivity was retrospectively assessed } \\
\text { using the Paroxysmal Sympathetic } \\
\text { Hyperactivity-Assessment Measure } \\
\text { (PSH-AM) scale in patients with severe } \\
\text { consciousness disorders. }\end{array}$ \\
\hline
\end{tabular}

MISTAKE The first line of the abstract is likely to be the first sentence of your paper that the reader will read. If they see a series of words (in italics in the NO! example) that give no indication as to what you did and found in your research, they may stop reading.

SOLUTION Shift key words/info to the beginning. Reduce the number of non-key words, i.e. words that do not add value for the reader

IMPACT If the reader sees the key words and key concepts immediately, they will be encouraged to read the rest of the Abstract, and hopefully the rest of the paper. 


\section{Abstracts: Make it clear why the purpose of your investigation is important.}

\begin{tabular}{|c|c|}
\hline NO! & YES! \\
\hline $\begin{array}{l}\text { Olive leaf extracts are of special interest for } \\
\text { their proven therapeutic effects although still } \\
\text { considered a by-product of table olive and } \\
\text { oil industry. The purpose of this research } \\
\text { was to investigate phytochemical profiles } \\
\text { and antioxidant activities in leaves of } 15 \\
\text { Italian Olea europaea L. cultivars grown in } \\
\text { the same pedoclimatic conditions. In order } \\
\text { to exploit a waste product, the phenolic } \\
\text { profiles and the amount of their seven } \\
\text { representative compounds were analyzed by } \\
\text { HPLC. }\end{array}$ & $\begin{array}{l}\text { Olive leaf extracts have proven therapeutic } \\
\text { effects. However, they are still considered a } \\
\text { by-product of the table olive and oil } \\
\text { industries. In order to learn possible ways of } \\
\text { exploiting this waste for health purposes, we } \\
\text { investigated the phytochemical profiles and } \\
\text { antioxidant activities in the leaves of } 15 \\
\text { Italian Olea europaea L. cultivars grown in } \\
\text { the same pedoclimatic conditions. The } \\
\text { phenolic profiles and amounts of their seven } \\
\text { representative compounds were analyzed by } \\
\text { HPLC. }\end{array}$ \\
\hline
\end{tabular}

MISTAKE In the NO example the reader is told the purpose of the research, but not the reason why this purpose is important.

SOLUTION Don't just tell the readers what you did, but also why you did it. Do this within the first three sentences of the abstract. Keep the sentences short - this will help to highlight the importance of what your research involves.

IMPACT If you tell your readers near the beginning of the abstract why you carried out your research, they are more likely to continue reading. If you just give them background info or make them wait too long before they discover the rationale underlying your research objectives, readers may simply stop reading. 


\section{Abstracts: Clearly differentiate between the state-of-the-art and what you did in your research.}

\begin{tabular}{|c|c|}
\hline NO! & YES! \\
\hline $\begin{array}{l}\text { The frequency of online racist attacks } \\
\text { during the first outbreak of Covid-19 in } \\
2020 \text { enable the classification of three } \\
\text { types of political and social actors posting } \\
\text { on social media. These types are: i) } \\
\text { conspiracy theorists, the alt-right in the } \\
\text { USA, and right-wing movements in } \\
\text { Europe. The frequency of the postings } \\
\text { have been calculated by executing CFD } \\
\text { transient analyses which are commonly } \\
\text { used in analysing racist statements. } \\
\text { Finally, the power is highlighted of the } \\
\text { social networks to destroy the lives of } \\
\text { innocent people. }\end{array}$ & $\begin{array}{l}\text { We used the frequency of online racist attacks } \\
\text { during the first outbreak of Covid-19 in } 2020 \\
\text { to identify three types of political and social } \\
\text { actors posting on social media. These types } \\
\text { were found to be: i) conspiracy theorists, the } \\
\text { alt-right in the USA, and right-wing } \\
\text { movements in Europe. We calculated the } \\
\text { frequency of the postings by executing CFD } \\
\text { transient analyses, which are commonly used } \\
\text { in analysing racist statements. Finally, we } \\
\text { highlighted the power of the social networks } \\
\text { to destroy the lives of innocent people. } \\
\text { In this paper, the frequency of online racist } \\
\text { attacks during the first outbreak of Covid-19 in } \\
2020 \text { was used to identify three types of } \\
\text { political and social actors posting on social } \\
\text { media. These types were found to be: i) } \\
\text { conspiracy theorists, the alt-right in the USA, } \\
\text { and right-wing movements in Europe. The } \\
\text { frequency of the postings was calculated by } \\
\text { executing CFD transient analyses, which are } \\
\text { commonly used in analysing racist statements. } \\
\text { Finally, the power of the social networks to } \\
\text { destroy the lives of innocent people was } \\
\text { highlighted. }\end{array}$ \\
\hline
\end{tabular}

MISTAKE In the abstract above, the authors were trying to describe their own work, i.e. what they did during their research. However, their style is confusing. In fact, in the NO version, the reader cannot be clear whether the authors are talking about their work or another author's work. This is because they use the passive form, and they use the present tense indifferently whether they are talking about their work or other people's work. By convention the past simple rather than the present simple is used to indicate what you did (as opposed to what is already known - present tense).

SOLUTION If your journal allows, use the personal form we. You can use it in combination with phrases such as in this work / paper / study, and this work / paper / study shows that ... Use the past simple (were calculated, rather than the present is calculated or the present prefect has been calculated) to indicate what you did. 
There are two solutions shown in the YES column. The first YES solution is written in a personal style using we and the verbs that describe what the authors did are in the past form. The reader is thus certain that the authors are talking about their work.

The second YES solution is written in an impersonal style using the passive form. However, it is still relatively clear when the authors are talking about their work (they use the past tense) and when they are talking about other researchers (they use the present tense, e.g. CFD transient analyses which are commonly used in analysing racist statements).

IMPACT If it is clear to the reader what your particular contribution is, he/she is more likely to continue reading the paper. This factor is even more important for the reviewers of your paper. If they don't understand what you did and how you are filling the gap in the state of the art, then they will be less inclined to recommend your paper for publication. 


\section{Structured Abstracts - Background: Be careful of tense usage.}

\begin{tabular}{|l|l|}
\hline NO! & YES! \\
\hline $\begin{array}{l}\text { Background: Plasma clearance of iohexol } \\
\text { proved to be a reliable and relatively } \\
\text { inexpensive method for glomerular filtration } \\
\text { rate (GFR) evaluation in different veterinary } \\
\text { species, included horses. In humans and } \\
\text { dogs, aging resulted in a progressive decline } \\
\text { in GFR, as a result of modifications in renal } \\
\text { architecture and reduction in renal reserve. }\end{array}$ & $\begin{array}{l}\text { Background: The plasma clearance of } \\
\text { iohexol has proved to be a reliable and } \\
\text { relatively inexpensive method to assess the } \\
\text { glomerular filtration rate (GFR) in several } \\
\text { veterinary species, including horses. In } \\
\text { has never been investigated in horses. }\end{array}$ \\
$\begin{array}{l}\text { hrogressive decline in GFR, as a result of } \\
\text { modifications in renal architecture and } \\
\text { reduction in renal reserve. The relationship } \\
\text { between aging and GFR has never been }\end{array}$ \\
investigated in horses.
\end{tabular}

MISTAKE This section is entitled Background, so you are not talking about what you did in your research, but about the state of the art, i.e. what we know at the moment. Thus 'has proved' indicates the situation until now, whereas the past tense (showed) would imply that you made this discovery. Likewise, aging resulted implies that you are talking about your work, whereas leads to means that you are talking in general, i.e. what is already known. On the other hand has never been is correct because it means from the past until now, and it implies that in this paper this topic will be investigated for the first time.

SOLUTION For details on tense usage in Abstracts and background information see:

\section{English for Writing Research Papers}

https://www.springer.com/gp/book/9783319260921

IMPACT If you use the correct tenses, readers will not be confused between what other researchers have done and what you did. 


\section{Abstracts: When writing a single paragraph, write it like a 'structured abstract'.}

\begin{tabular}{|c|c|}
\hline NO! & YES! \\
\hline $\begin{array}{l}\text { In this paper we investigate whether } \\
\text { clomiphene citrate (CC) treatment affect the } \\
\text { biosynthesis and metabolism of both sexual } \\
\text { hormones and glucocorticoid in functional } \\
\text { obese hypogonadal men, considering the } \\
\text { presence of both LH and estrogen receptors } \\
\text { on both the gonadal and adrenal glands. CC } \\
\text { treatment in functional male hypogonadism } \\
\text { has been shown to increase endogenous } \\
\text { serum T and estrogen levels by stimulating } \\
\text { Luteinizing Hormone (LH) and Follicle } \\
\text { Stimulating Hormone (FSH) secretion from } \\
\text { hypothalamus and pituitary gland. We } \\
\text { observed that the fold changes induced by } \\
\text { CC compared with those observed after } \\
\text { Plac, were significantly higher for .. }\end{array}$ & $\begin{array}{l}\text { In this paper we show that CC therapy can } \\
\text { stimulate the steroidogenesis both in the testis } \\
\text { and in the adrenal gland, as was proved by the } \\
\text { rise in serum testosterone (T) and cortisol (F) } \\
\text { levels in all our participants. Furthermore, .... } \\
\text { CC treatment in functional male } \\
\text { hypogonadism has been shown to increase } \\
\text { endogenous serum T and estrogen levels by } \\
\ldots . \text { We adopted a randomized cross-over } \\
\text { double blind controlled study (RCT) using ... } \\
\text { A total of } 21 \text { out of the } 24 \text { enrolled obese } \\
\text { hypogonadal men concluded the study. } \\
\text { Inclusion criteria were: ... We observed that } \\
\text { the fold changes induced by CC compared } \\
\text { with those observed after Plac, were } \\
\text { significantly higher for .... Although this } \\
\text { study is the first to detect an effect of CC on } \\
\text { both testicular and adrenal steroidogenesis. } \\
\text { However, ... In conclusion, CC is able to } \\
\text { increase T production in obese dysnetabolic } \\
\text { hypogonadal patients and should be } \\
\text { considered as ... }\end{array}$ \\
\hline
\end{tabular}

MISTAKE One of the biggest mistakes in writing an abstract is to forget that the abstract is a summary of the entire paper. The NO! example is little more than an introduction to the topic with some results. The author has forgotten to mention the methods, limitations and implications. Note however that not all journals require you to mention the limitations and implications in your abstract.

SOLUTION To avoid this problem, imagine that you are writing a structured abstract. If you answer the questions / headings typically used in a structured abstract, then you will remember to include everything. You will then produce an abstract like the YES example in the left-hand column.

EXAMPLE OF STRUCTURED ABSTRACT

Summary answer: CC therapy can ... Furthermore, ....

What is known already: CC treatment has been shown to.... 
Study design, size, duration: This was a randomized cross-over double blind controlled study (RCT) using ...

Participants/materials, setting, methods: 21 out of the 24 enrolled men concluded the study. Inclusion criteria were: ...

Main results and the role of chance: We observed that....

Limitations, reasons for caution: This study is the first to ... However, ...

Wider implications of the findings: $\mathrm{CC}$ is able to increase $\mathrm{T}$ production and should be considered as ...

IMPACT Readers read an abstract to understand what the whole paper is about. By using a structured abstract as a template you will provide readers and reviewers with all the standard information that is required. 


\section{Abstract and Introduction: Avoid the word 'attempt' and avoid making bold statements beginning with 'this is the first ...".}

\begin{tabular}{|l|l|}
\hline NO! & YES! \\
\hline $\begin{array}{l}\text { This study is the first attempt to address } \\
\text { a fundamental question: How does color } \\
\text { impact on human decision marking? }\end{array}$ & $\begin{array}{l}\text { To the best of our knowledge, this study is the } \\
\text { first to address the following fundamental } \\
\text { question: How does color impact on human } \\
\text { decision making? }\end{array}$ \\
\hline
\end{tabular}

MISTAKE The word attempt is a little misleading - it suggests that you tried to do something but doesn't tell the reader whether you actually succeeded or not.

Saying this is the first time ... may be dangerous because you can rarely be $100 \%$ sure that you are the first to do something.

SOLUTION Remove attempt. Precede this is the first time with one of the following: to the best of our knowledge ... we believe that ... as far as we are aware...

IMPACT By removing attempt you clarify for the reader that you succeeded in your task. By adding to the best of our knowledge you protect yourself from possible criticism by the reviewers that in reality this is not the first time. If your overall tone is confident but not arrogant, you will gain the trust of your readers. 